\title{
Meta-Analysis the Effect of School Based Intervention on Smoking in Adolescents
}

\section{Muhammad Rifqi Azhary'), Eti Poncorini Pamungkasari²), Yulia Lanti Retno Dewi ${ }^{2)}$}

\author{
1)Masters Program in Public Health, Universitas Sebelas Maret \\ 2)Department of Public Health, Faculty of Medicine, Universitas Sebelas Maret
}

\section{ABSTRACT}

Background: Tobacco is a global problem, in which at least 5 million people die from diseases caused by the consumption of tobacco products such as cigarettes each year, such as cervical cancer, heart disease, gastric ulcers, tuberculosis, kidney failure, pancreas, leukemia, pneumonia, gum and mouth disease as well as lung cancer. This study aims to estimate the magnitude of the effect of School based intervention on cigarette consumption based on the results of a number of previous studies.

Subjects and Method: This research is a systematic study and meta-analysis, with PICO as follows Population = junior high school and high school students, Intervention $=$ School based intervention. Comparison $=$ No School based intervention. Outcome = cigarette consumption. The articles used in this study were obtained from several databases including PubMed, ScienceDirect and Google Scholar. This article article was collected for 2 months. The keywords for searching articles are as follows: "Schoolbased intervention" AND tobacco OR smoke OR cigarette AND RCT OR "Randomized
Controlled Trial". The articles included in this study are full text articles with a randomized controlled trial study design. Articles were collected using PRISMA flow diagrams. They were analyzed using the Review Manager 5.3 application.

Results: A total of $\mathbf{1 1}$ articles reviewed in this meta-analysis study originated from the United States, Sweden, California, Brazil, Germany, Ireland, China, Australia and Indonesia. Studies show that School based intervention has no significant effect on cigarette consumption (Standardized Mean Difference $=-0.74 ; 95 \% \mathrm{CI}=-1.67$ to $0.18 ; \mathrm{p}$ $=0.110$ ).

Conclusion: School based intervention reduces cigarette consumption.

Keywords: School based intervention, tobacco, cigarette consumption

\section{Correspondence:}

Muhammad Rifqi Azhary. Masters Program In Public Health, Universitas Sebelas Maret. Jl. Ir. Sutami 36A, Surakarta 57126, Central Java. Email: Rifqiazhary.ra@gmail.com.

Cite this as:

Azhary MR, Pamungkasari EP, Dewi YLR (2021). Meta-Analysis the Effect of School Based Intervention on Smoking in Adolescents. J Health Promote Behav. 06(01): 32-44. https://doi.org/10.26911/thejhpb.2021.06.01.04.

\section{BACKGROUND}

Adolescence or school students is a period where adolescents find their identity, a period where adolescents become unstable, making them vulnerable to delinquency and the problems they will face, such as promiscuity, drugs, alcohol, and cigarettes that threaten health. According to the GYTS Survey, 25\% of school students become active smokers. Adolescents are the easiest targets to be influenced by tobacco product manufacturers, with $75 \%$ of school students having seen tobacco product advertisements. With this exposure, school students 
Azhary et al./ The Effect of School Based Intervention on Smoking in Adolescents

have high potential to become active smokers until adulthood (Islami et al., 2019).

Tobacco is a global problem, where at least 5 million people die from diseases caused by tobacco consumption every year. Such as cervical cancer, heart disease, gastric ulcers, tuberculosis, kidney failure, pancreas, leukemia, pneumonia, gum and mouth disease, and lung cancer (Cahill et al., 2012; MINISTRY OF HEALTH, 2017) This number will continue to increase if the problem is tobacco is not treated quickly and appropriately. It is estimated that around 10 million people die in 2030, of which $70 \%$ of deaths occur in developing countries. Deadly diseases including diseases caused by the use of tobacco products know no national boundaries, each country can also get the impact of the dangers of tobacco products (FCTC, 2005).

The Tobacco Atlas stated that the number of cigarette consumption in the world in 2014 reached 5.8 trillion sticks and is still increasing every year. The prevalence of smoking in developed countries has decreased, but on the contrary in developing countries it is increasing. The results of a study in the medical journal The Lancet Infectious Diseases show that smoking cessation rates are low in most developing countries. Developed countries such as Japan and Singapore make smoking bans in various places, especially tourist spots and public places, even smokers are prohibited from smoking while walking on the highway. In America, the price of cigarettes is quite expensive and not easy to get anywhere. Cigarettes are easily available in developing countries at relatively cheap prices. Cigarette advertisements in developing countries appear 81 times more often than in high-income countries. One of the developing countries with the largest cigarette consumption is Indonesia, which in 2014 was ranked fourth after China, Russia and America. Indonesia occupies the first position in the country with the largest percentage of male smokers aged 15 years and over in the world. Data from The Tobacco Atlas 2015 states that $66 \%$ of men in Indonesia smoke. Russia is in second place with $60 \%$ of male smokers over 15 years of age. Then followed by China (53\%), Philippines (48\%), Vietnam (47\%), Malaysia (44\%), India (24\%), and Brazil (22\%) (Drope et al., 2018).

There are many tobacco products scattered throughout the world. All of these products are products that threaten health and even cause death due to diseases caused by tobacco consumption. Tobacco products include e-cigarettes, cigarettes, cigars, smokeless tobacco, pipe and hookahs. In 2019, 1 in 4 middle and high school students have tried to consume tobacco products and 3 out of 10 students are active smokers until now (CDC, 2020).

The FCTC or Framework Convention on Tobacco Control is an association formed at the 56th session of the World Health Assembly (WHO) in May 2003 which was attended by 192 WHO member countries unanimously adopting the framework of the tobacco control convention to control the world tobacco epidemic. 172 countries or $87.30 \%$ of the world's population are FCTC participants, 168 countries or 91.58\% of the world's population have signed the FCTC agreement, 183 countries or 94.89 of the world's population are members of the FCTC and 195 countries are eligible to become FCTC participants (FCTC, 2005).

Cigarettes are a world problem that is touted as a disease of children and the tobacco epidemic. Many junior and senior high school students have started smoking, some of whom started smoking at 18 years of age, and some who started smoking at 
less than 10 years of age. 10\% of smokers are students aged 13-15 years. According to the statistical data collected, WHO estimates that there will be continuous use or consumption of cigarettes which results in the death of 250 million children and adolescents. There are various factors that cause children and adolescents to smoke, including cultural norms, tobacco distribution, and tobacco control policies and strategies and the tobacco industry in promoting cigarette products which indirectly weakens government strategies and policies (WHO, 2014).

Cigarettes are tobacco products that are rolled using paper with or without using a filter. Cigarettes contain substances that are very dangerous to health, among others; Acetone, Hydrogen Cyanide, Toluidine, Ammonia, Urethane, Toluene, Arsenic, Dibenzacridine, Phenol, Butane, Polonium, Naphtylamine, Methanol, Pyrene, Dimethylnitrosamine, Naphtalene, Cadmium, Carbon Monoxide, Benzopyrene, and Vinyl Chloride. There are many compounds and substances that threaten health and life. There are 4000 types of chemical compounds, 400 hazardous substances and 43 cancer-causing substances (carcinogenic). Carbon monoxide (CO) is a poisonous gas, lowers oxygen levels in the blood, so that it can reduce concentrations and the emergence of dangerous diseases, Tar is a substance that causes cancer and various other diseases, while nicotine is a dangerous substance that causes addiction or addiction (Ministry of Health, 2017 ).

There are several reasons why school students use tobacco products, including social and physical environment, biological and genetic factors, mental health, personal views, and other influences such as tobacco product advertising, family support and attention, socio-economic and school attention. Many policies have been imple- mented, such as increasing cigarette prices, limiting the use of cigarettes in several places and making regulations on the age that can buy tobacco products to 21 years. These policies cannot fully control cigarette consumption (CDC, 2020). Therefore, school-based interventions are very important in addressing the problem of cigarette consumption among school students. Given that students spend more of their time in school, of course the role of teachers and schools is very much needed to educate students to live healthy, especially not to smoke or to stop smoking for students who already smoke.

Based on the background and some of the things above, it is known that cigarette consumption among students continues to increase due to easy access to cigarettes and the lack of control in students so that research on "Meta-analysis of the effect of School-based intervention on cigarette consumption" needs to be done, considering that adolescents spend more time at school than at home. So that researchers are interested in conducting this research.

\section{SUBJECTS AND METHOD}

\section{Study Design}

This was a systematic study and metaanalysis. The articles used in this study were obtained from several databases including PubMed, ScienceDirect and Google Scholar. The keywords for searching articles are as follows: "School-based intervention" AND tobacco OR smoke OR cigarette AND RCT OR "Randomized Controlled Trial".

\section{Inclusion Criteria}

The article included in this study is a full paper article with a randomized controlled trial study design. The research subjects were junior high school and senior high school students. Selected articles provide an intervention in the form of School based 
Azhary et al./ The Effect of School Based Intervention on Smoking in Adolescents

intervention with cigarette consumption outcomes.

\section{ExclusionCriteria}

Articles published in this study are articles that are not in English or Indonesian, research designs other than RCTs, articles that are not full text, articles published before 2000.

\section{Operational Definition of Variables}

The article search was carried out by considering the eligibility criteria defined using the PICO model. The population in the study were junior high school and high school students, intervention in the form of School based intervention, comparison, namely not school based intervention and outcome in the form of cigarette consumption.

School based intervention is a program to prevent and reduce cigarette consumption by schools or using third parties held in schools. Instrument: School-based program (youth resilience intervention) with a categorical measurement scale.
Cigarette consumption is the intensity of smoking or the number of cigarettes consumed. Instruments: ASSIST questionnaire or Alcohol, smoking and substance involvement screening test questionnaire with a continuous measurement scale.

\section{Data Analysis}

Data processing was carried out by the Review Manager (RevMan 5.3) by calculating the mean difference to determine the research model that was combined and formed the final meta-analysis result.

\section{RESULTS}

The process of searching for articles by searching through a database with journals can be seen in Figure 1.

Figure 2 shows the areas where articles were drawn according to the inclusion criteria. Articles obtained from 4 continents, namely America, Europe, Australia and Asia.

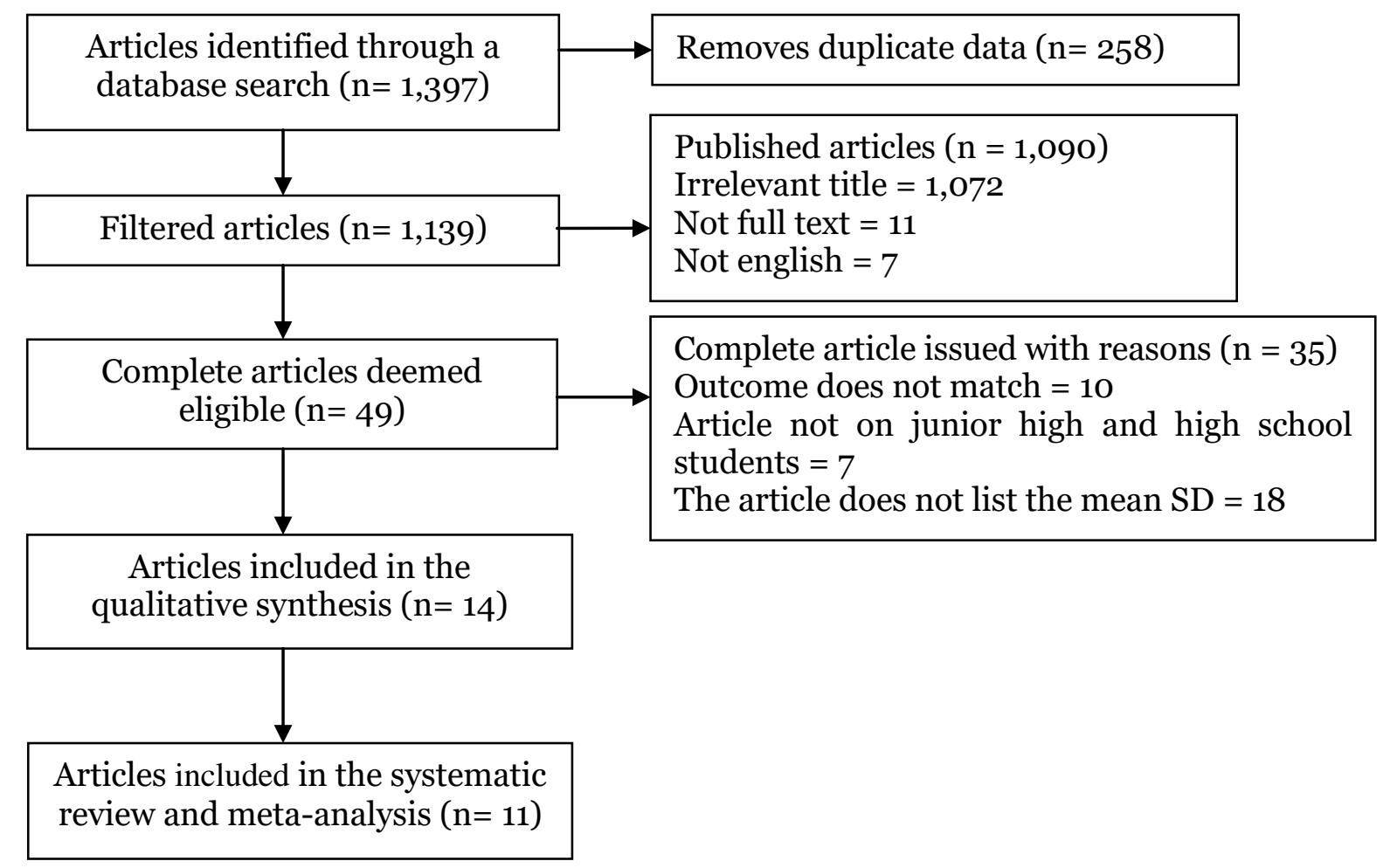

Figure 1. PRISMA flow diagram 
Table 1. Assessment of Study Quality

\begin{tabular}{|c|c|c|c|c|c|c|c|c|c|c|c|}
\hline \multirow[b]{2}{*}{$\begin{array}{l}\text { Checklist } \\
\text { questions }\end{array}$} & \multicolumn{11}{|c|}{ Publication (Author and Year) } \\
\hline & $\begin{array}{l}\text { Blaakman } \\
\text { et al. } \\
\text { (2011) }\end{array}$ & $\begin{array}{l}\text { Sarin } \\
\text { et al. } \\
(2013)\end{array}$ & $\begin{array}{c}\text { Sun } \\
\text { et al. } \\
(2007)\end{array}$ & $\begin{array}{l}\text { Lisboa } \\
\text { et al. } \\
\text { (2019) }\end{array}$ & $\begin{array}{l}\text { Gianota } \\
\text { et al. } \\
(2013)\end{array}$ & $\begin{array}{l}\text { Muller } \\
\text { et al. } \\
\text { (2014) }\end{array}$ & $\begin{array}{l}\text { Tahlil } \\
\text { et al. } \\
\text { (2013) }\end{array}$ & $\begin{array}{l}\text { Tahlil } \\
\text { et al. } \\
\text { (2015) }\end{array}$ & $\begin{array}{l}\text { Wen } \\
\text { et al. } \\
\text { (2010) }\end{array}$ & $\begin{array}{c}\text { Thruston } \\
\text { et al. } \\
\text { (2018) }\end{array}$ & $\begin{array}{c}\text { Hodder } \\
\text { et al. } \\
(\mathbf{2 0 1 7})\end{array}$ \\
\hline $\begin{array}{l}\text { Does this study } \\
\text { address a clear } \\
\text { research focus? }\end{array}$ & 1 & 1 & 1 & 1 & 1 & 1 & 1 & 1 & 1 & 1 & 1 \\
\hline $\begin{array}{l}\text { Is the Randomized } \\
\text { Controlled Trial } \\
\text { research method } \\
\text { suitable for } \\
\text { answering research } \\
\text { questions? }\end{array}$ & 1 & 1 & 1 & 1 & 1 & 1 & 1 & 1 & 1 & 1 & 1 \\
\hline $\begin{array}{l}\text { Are there enough } \\
\text { subjects in the } \\
\text { study to establish } \\
\text { that the findings } \\
\text { were not made by } \\
\text { chance? }\end{array}$ & 1 & 1 & 1 & 1 & 1 & 1 & 1 & 1 & 1 & 1 & 1 \\
\hline $\begin{array}{l}\text { Were subjects } \\
\text { randomly allocated } \\
\text { to the experimen- } \\
\text { tal and control } \\
\text { groups? If not, } \\
\text { could this be } \\
\text { biased? }\end{array}$ & o & 1 & 1 & 1 & 1 & o & 1 & 1 & $\mathrm{o}$ & 1 & o \\
\hline $\begin{array}{l}\text { Are inclusion / } \\
\text { exclusion criteria } \\
\text { used? }\end{array}$ & 1 & 1 & 1 & 1 & 1 & 1 & 1 & 1 & 1 & 1 & 1 \\
\hline $\begin{array}{l}\text { Were the two } \\
\text { groups comparable } \\
\text { at study entry? }\end{array}$ & o & 1 & O & 1 & 1 & o & O & 1 & 1 & 1 & 1 \\
\hline
\end{tabular}


Azhary et al./ The Effect of School Based Intervention on Smoking in Adolescents

Are objective and unbiased outcome criteria?

Are objective and

validated measure-

ment methods

used to measure

the results? If not,

were the results

scored by someone

who did not know

the group assign-

ment (i.e. was the

grading blended)?

Is the effect size

practically

relevant?

How precise is the

estimated effect? Is

there a confidence

interval?

confounding

factors that have

not been taken into

account?

Are the results

applicable to your

research?
Could there be

1

1

1

1

1

1

1

1

1

1

1

1

1

1

1

Total 


\section{School based intervention in cigarette consumption}

11 The article proves that there is a relationship between School based intervention in cigarette consumption

Table 2. Descriptions of primary studies included in the primary study meta-analysis

\begin{tabular}{|c|c|c|c|c|c|c|c|}
\hline $\begin{array}{l}\text { Author } \\
\text { (Year) }\end{array}$ & Country & $\begin{array}{l}\text { Study } \\
\text { Design }\end{array}$ & Sample & $\begin{array}{c}\mathbf{P} \\
\text { (Population) }\end{array}$ & $\begin{array}{c}\text { I } \\
\text { (Intervention) }\end{array}$ & $\begin{array}{c}\mathrm{C} \\
\text { (Comparison) }\end{array}$ & $\begin{array}{c}\text { O } \\
\text { (Outcome) }\end{array}$ \\
\hline $\begin{array}{ll}\text { Blaakman } & \text { et } \\
\text { al. (2011). } & \end{array}$ & $\begin{array}{l}\text { Amerika } \\
\text { Serikat }\end{array}$ & $\begin{array}{l}\text { Randomized } \\
\text { Controlled } \\
\text { Trial. }\end{array}$ & $\begin{array}{l}\text { SBI : } 111 \\
\text { No intervention: } \\
29\end{array}$ & JHS & $\begin{array}{l}\text { Looking at the potential effects } \\
\text { of School based intervention } \\
\text { on consumption of smoking * } \\
\text { alcohol and drugs. }\end{array}$ & $\begin{array}{l}\text { Did not see the potential } \\
\text { effect of School based } \\
\text { intervention on } \\
\text { consumption of smoking *, } \\
\text { alcohol and drugs }\end{array}$ & $\begin{array}{l}\text { Consumption } \\
\text { of cigarettes *, } \\
\text { alcohol and } \\
\text { illegal drugs }\end{array}$ \\
\hline $\begin{array}{l}\text { Sarin et al. } \\
(2013) \text {. }\end{array}$ & $\begin{array}{l}\text { Amerika } \\
\text { Serikat }\end{array}$ & $\begin{array}{l}\text { Randomized } \\
\text { Controlled } \\
\text { Trial. }\end{array}$ & $\begin{array}{l}\text { SBI : } 26 \\
\text { No intervention: } \\
25\end{array}$ & SHS & $\begin{array}{l}\text { Analyzing the intervention } \\
\text { from School based } \\
\text { intervention on smoking } \\
\text { behavior and cigarette } \\
\text { consumption * as well as } \\
\text { analyzing the long and short } \\
\text { term effects. }\end{array}$ & $\begin{array}{l}\text { No Analyzing interventions } \\
\text { from School based } \\
\text { intervention on smoking } \\
\text { behavior and cigarette } \\
\text { consumption * as well as } \\
\text { analyzing long and short } \\
\text { term effects. }\end{array}$ & $\begin{array}{l}\text { Consumption } \\
\text { of cigarettes }\end{array}$ \\
\hline $\begin{array}{l}\text { Thurston et al. } \\
\text { (2018). }\end{array}$ & Irlandia & $\begin{array}{l}\text { Randomized } \\
\text { Controlled } \\
\text { Trial. }\end{array}$ & $\begin{array}{l}\text { SBI : } 150 \\
\text { No intervention: } \\
141\end{array}$ & JHS & $\begin{array}{l}\text { Assessing the efficacy of a } \\
\text { school-based intervention } \\
\text { program on smoking-related } \\
\text { outcomes in Grade } 8 \text { school } \\
\text { students. }\end{array}$ & $\begin{array}{l}\text { Does not assess the efficacy } \\
\text { of a school based } \\
\text { intervention program on } \\
\text { smoking-related outcomes } \\
\text { in Grade } 8 \text { school students. }\end{array}$ & $\begin{array}{l}\text { Consumption } \\
\text { of cigarettes }\end{array}$ \\
\hline $\begin{array}{l}\text { Giannota et al. } \\
\text { (2013). }\end{array}$ & Swedia & $\begin{array}{l}\text { Randomized } \\
\text { Controlled } \\
\text { Trial. }\end{array}$ & $\begin{array}{l}\text { SBI : } 143 \\
\text { No intervention: } \\
143\end{array}$ & SHS & $\begin{array}{l}\text { Analyzing the School Based } \\
\text { Intervention on the use of } \\
\text { tobacco *, alcohol, and } \\
\text { marijuana. }\end{array}$ & $\begin{array}{l}\text { Not Analyzing School } \\
\text { Based Intervention on the } \\
\text { use of tobacco *, alcohol, } \\
\text { and marijuana. }\end{array}$ & $\begin{array}{l}\text { Consumption } \\
\text { of cigarettes *, } \\
\text { alcohol and } \\
\text { marijuana }\end{array}$ \\
\hline $\begin{array}{l}\text { Wen et al. } \\
(2010) .\end{array}$ & China & $\begin{array}{l}\text { Randomized } \\
\text { Controlled } \\
\text { Trial. }\end{array}$ & $\begin{array}{l}\text { SBI : } 626 \\
\text { No intervention } \\
: 357\end{array}$ & JHS & $\begin{array}{l}\text { Assessing School Based } \\
\text { Intervention in standard } \\
\text { health curricula on attitudes, } \\
\text { behavior and * consumption of } \\
\text { cigarettes. }\end{array}$ & $\begin{array}{l}\text { Not Assessing School Based } \\
\text { Intervention in standard } \\
\text { health curricula on } \\
\text { attitudes, behaviors and * } \\
\text { cigarette consumption. }\end{array}$ & $\begin{array}{l}\text { Consumption } \\
\text { of cigarettes }\end{array}$ \\
\hline $\begin{array}{l}\text { Tahil et al. } \\
(2013) \text {. }\end{array}$ & Indonesia & $\begin{array}{l}\text { Randomized } \\
\text { Controlled } \\
\text { Trial. }\end{array}$ & $\begin{array}{l}\text { SBI : } 239 \\
\text { No intervention } \\
: 226\end{array}$ & JHS & $\begin{array}{l}\text { This study aims to test the } \\
\text { effectiveness of the School } \\
\text { Based Intervention on } \\
\text { smoking habits. }\end{array}$ & $\begin{array}{l}\text { It does not aim to test the } \\
\text { effectiveness of the School } \\
\text { Based Intervention on } \\
\text { smoking habits. }\end{array}$ & $\begin{array}{l}\text { Consumption } \\
\text { of cigarettes }\end{array}$ \\
\hline
\end{tabular}




\begin{tabular}{|c|c|c|c|c|c|c|c|}
\hline $\begin{array}{c}\text { Author } \\
\text { (Year) }\end{array}$ & Country & $\begin{array}{l}\text { Study } \\
\text { Design }\end{array}$ & Sample & $\begin{array}{c}\mathbf{P} \\
\text { (Population) }\end{array}$ & $\begin{array}{c}\text { I } \\
\text { (Intervention) }\end{array}$ & $\begin{array}{c}\mathrm{C} \\
\text { (Comparison) }\end{array}$ & $\begin{array}{c}\text { O } \\
\text { (Outcome) }\end{array}$ \\
\hline $\begin{array}{l}\text { Sun et al. } \\
(2007) \text {. }\end{array}$ & California & $\begin{array}{l}\text { Randomized } \\
\text { Controlled } \\
\text { Trial. }\end{array}$ & $\begin{array}{l}\text { SBI : } 487 \\
\text { No intervention } \\
: 391\end{array}$ & JHS & $\begin{array}{l}\text { To assess the effectiveness of } \\
\text { the School Based Intervention } \\
\text { in affecting smoking } \\
\text { consumption. }\end{array}$ & $\begin{array}{l}\text { No To assess the } \\
\text { effectiveness of the School } \\
\text { Based Intervention on } \\
\text { smoking consumption *. }\end{array}$ & $\begin{array}{l}\text { Consumption } \\
\text { of cigarettes. }\end{array}$ \\
\hline $\begin{array}{l}\text { Tahlil et al. } \\
\text { (2015) }\end{array}$ & Indonesia & $\begin{array}{l}\text { Randomized } \\
\text { Controlled } \\
\text { Trial. }\end{array}$ & $\begin{array}{l}\text { SBI }: 109 \\
\text { No intervention } \\
: 107\end{array}$ & JHS & $\begin{array}{l}\text { To investigate the impact of } \\
\text { School Based Intervention, on } \\
\text { the prevalence of cigarette } \\
\text { consumption }\end{array}$ & $\begin{array}{l}\text { No To investigate the } \\
\text { impact of School Based } \\
\text { Intervention, on the } \\
\text { prevalence of cigarette } \\
\text { consumption }\end{array}$ & $\begin{array}{l}\text { Consumption } \\
\text { of cigarettes }\end{array}$ \\
\hline $\begin{array}{l}\text { Muller et al. } \\
\text { (2014) }\end{array}$ & Jerman & $\begin{array}{l}\text { Randomized } \\
\text { Controlled } \\
\text { Trial. }\end{array}$ & $\begin{array}{l}\text { SBI }: 1142 \\
\text { No intervention } \\
: 679\end{array}$ & JHS and SHS & $\begin{array}{l}\text { Evaluating smoking } \\
\text { prevention strategies in school } \\
\text { students with School based } \\
\text { intervention }\end{array}$ & $\begin{array}{l}\text { No Evaluating smoking } \\
\text { prevention strategies in } \\
\text { school students with School } \\
\text { based intervention }\end{array}$ & $\begin{array}{l}\text { Consumption } \\
\text { of cigarettes }\end{array}$ \\
\hline $\begin{array}{l}\text { Lisboaet al. } \\
\text { (2019) }\end{array}$ & Brazil & $\begin{array}{l}\text { Randomized } \\
\text { Controlled } \\
\text { Trial. }\end{array}$ & $\begin{array}{l}\text { SBI : } 116 \\
\text { No intervention } \\
: 127\end{array}$ & JHS and SHS & $\begin{array}{l}\text { Measuring the effectiveness of } \\
\text { the Education curriculum } \\
\text { against tobacco in schools on } \\
\text { cigarette consumption }\end{array}$ & $\begin{array}{l}\text { Not Measuring the } \\
\text { effectiveness of the } \\
\text { Education against tobacco } \\
\text { curriculum in schools on } \\
\text { cigarette consumption }\end{array}$ & $\begin{array}{l}\text { Consumption } \\
\text { of cigarettes }\end{array}$ \\
\hline $\begin{array}{l}\text { Hodderet al. } \\
\text { (2017) }\end{array}$ & Australia & $\begin{array}{l}\text { Randomized } \\
\text { Controlled } \\
\text { Trial. }\end{array}$ & $\begin{array}{l}\text { SBI : } 406 \\
\text { No intervention } \\
: 235\end{array}$ & JHS and SHS & $\begin{array}{l}\text { Investigating the effectiveness } \\
\text { of School based intervention in } \\
\text { the use of tobacco or cigarettes } \\
{ }^{*} \text {, alcohol and illegal drugs }\end{array}$ & $\begin{array}{l}\text { Not investigating the } \\
\text { effectiveness of School } \\
\text { based intervention in the } \\
\text { use of tobacco or cigarettes } \\
\text { *, alcohol and illegal drugs }\end{array}$ & $\begin{array}{l}\text { Consumption } \\
\text { of cigarettes *, } \\
\text { alcohol and } \\
\text { illegal drugs }\end{array}$ \\
\hline
\end{tabular}

*Variables included in the meta-analysis

SBI : School Based Intervention 
Azhary et al./ The Effect of School Based Intervention on Smoking in Adolescents

\section{Forest plot}

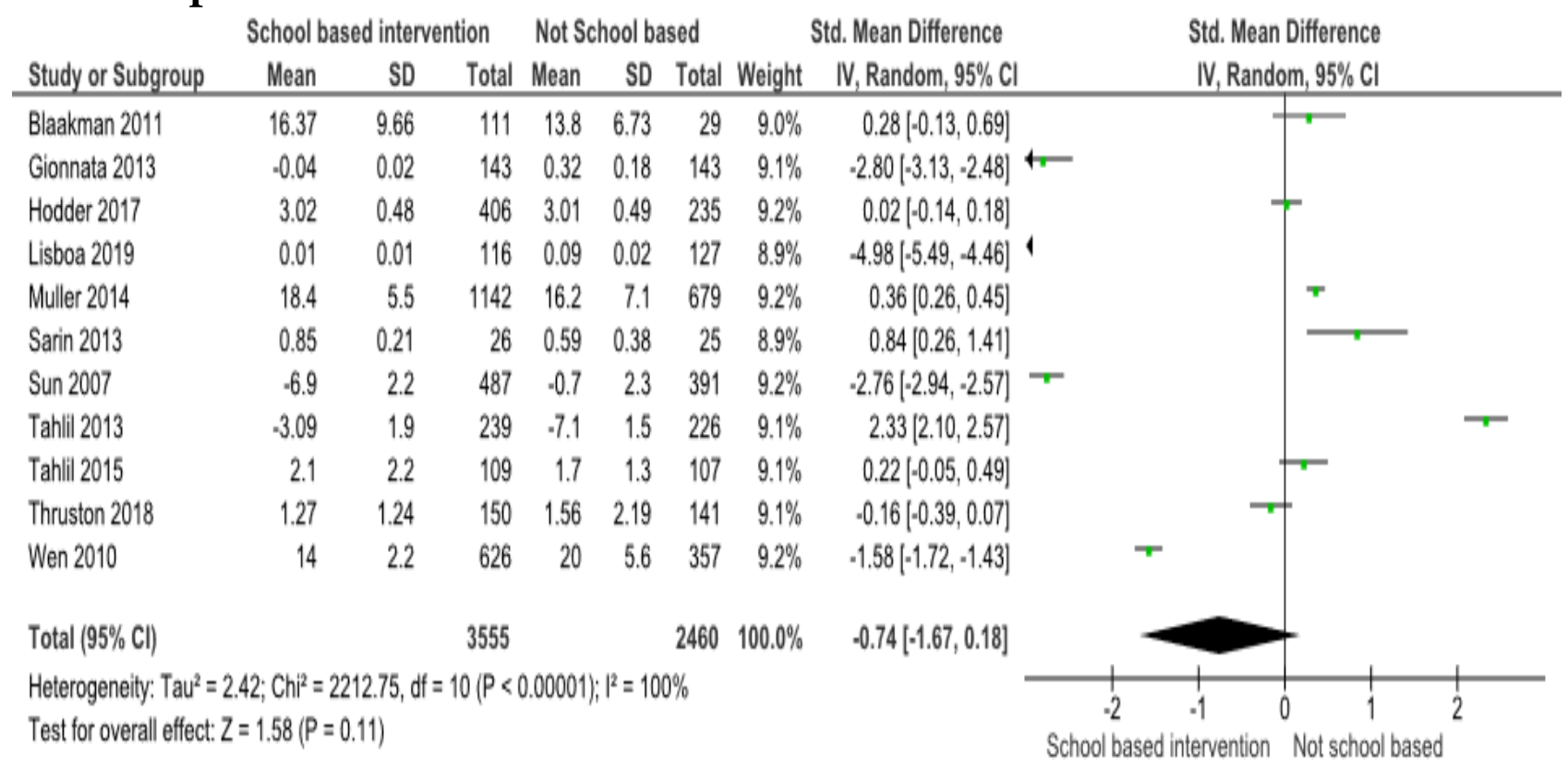

\section{Figure 3. Forest plot for the effect of School based intervention against cigarette consumption}

\section{Funnel plot}

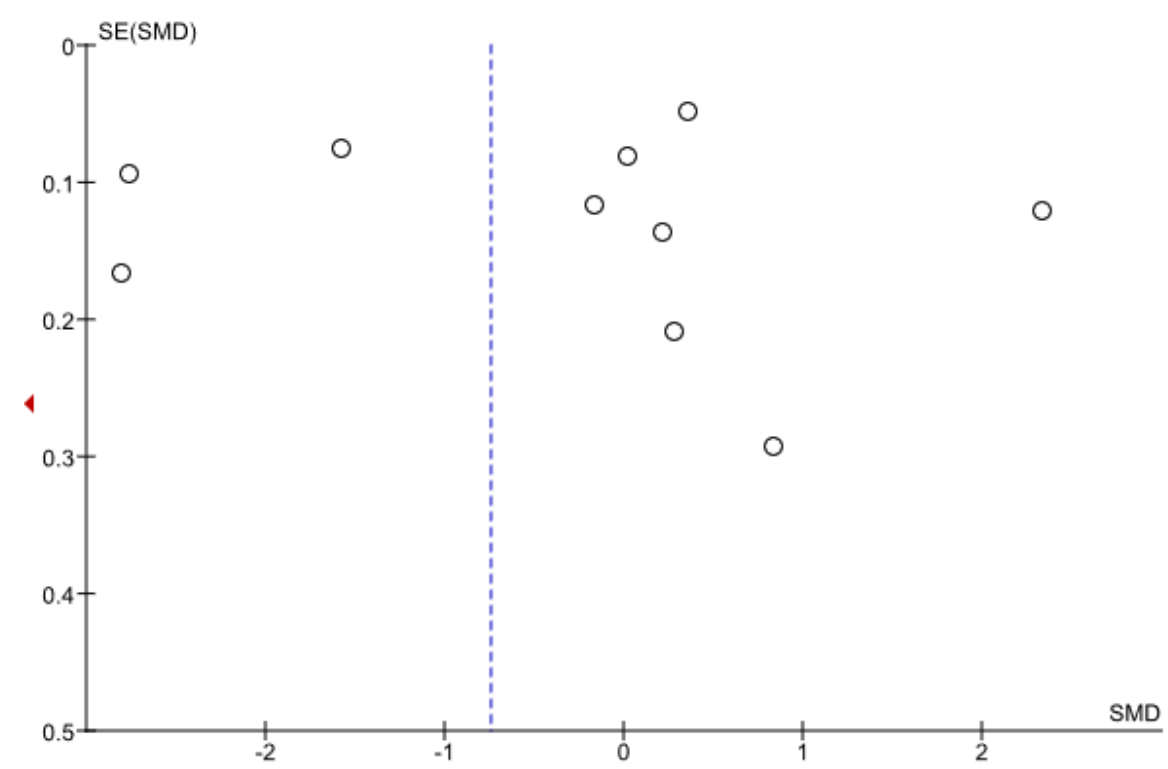

Figure 4. Funnel plot of the effect of School based intervention on cigarette consumption

Based on the results of the forest plot (Figure 3), it shows that School-based intervention -0.74 units affects cigarette consumption and it is not statistically significant $(\mathrm{p}=0.110)$. The heterogeneity of the research data shows I $2=100 \%$ so that the distribution of the data is heterogeneous (random effect model).

The funnel plot (figure 4) shows a publication bias which is characterized by 
asymmetry of the right and left plots where 4 plots are on the left and 7 plots are on the right. The plot on the left has a standard error between 0.0 and 0.2 and the plot on the right has a standard error between 0.0 and 0.3 .

\section{DISCUSSION}

This systematic study and meta-analysis research raises the theme of the effect of School-based intervention on cigarette consumption. This study discusses data on cigarette consumption which is considered important because of the high rate of cigarette consumption, especially among school children.

Confounding factors affect the relationship or effect of exposure to the occurrence of disease estimated (predicted) by the study is not the same as the relationship or effect that actually occurs in the target population, or the results of the study are invalid (not true) (Murti, 2018a). This systematic study and meta-analysis uses research that has controlled for confounding factors which can be seen from the research inclusion requirements, namely the standardized mean difference.

The estimated combined effect of School-based intervention on cigarette consumption was processed using RevMan 5.3 with the Continous method, this method was used to analyze the effect size or standardized mean difference in the bivariate data of two groups that had been controlled for confounding factors by randomization.

The results of the systematic study and meta-analysis are presented in the form of a forest plot and a funnel plot. Forest plots provide an overview of information from each of the studies examined in the meta-analysis, and estimates of the overall results (Murti, 2018a). The forest plot shows visually the amount of variation (heterogeneity) between study results (Akobeng in Murti, 2018a).

A funnel plot is a diagram in a metaanalysis used to demonstrate possible publication bias. The funnel plot shows the relationship between the effect size of the study and the sample size or standard error of the effect size of the various studies studied (Murti, 2018a).

The funnel plot shows visually the amount of variation (heterogeneity) (Akobeng, 2005 in Murti, 2018a). The funnel plot shows the relationship between the effect size of the study and the sample size of the various studies studied, which can be measured in a number of different ways (Murti, 2018a).

Systematic review and meta-analysis in this study were conducted with the aim of increasing the generalizability of the findings and obtaining convincing conclusions from the results of various similar studies regarding school-based intervention -0.74 units affecting cigarette consumption.

The results of the forest plot show that School-based intervention -0.74 units affects cigarette consumption, compared to without intervention. (SMD $=-0.74 ; 95 \% \mathrm{CI}$ -1.67 to $0.18 \mathrm{p}=0.110$ ). The heterogeneity of the research data shows $\mathrm{I}^{2}=100 \%$ so that the distribution of the data is stated to be heterogeneous (random effect model).

Hodder et al (2017) states that school based intervention or intervention conducted by schools in the form of adolescent resilience interventions has not been proven to significantly reduce cigarette consumption in school children due to several things such as lack of resources from schools to run or provide maximum intervention to students, as well as the lack of time the interventions are carried out. In his research, he recommends a combination of interventions to prevent or reduce 
cigarette consumption in school students, such as combining School based intervention, Family based intervention and Peer based intervention so that students get protection or resilience from various sides, such as from family, school and peers.

This study is in line with the research of Robinson et al. (2003) which states that both the intervention group and the control group tend to show the same changes in smoking behavior, so that the School based intervention has not been able to show significant evidence of its effect on cigarette consumption. In his research, he recommends developing a good methodology and randomizing schools and students as research samples to be in different environments. Because in his research it was stated that the factors that caused the failure of the intervention, one of which was that students who were the intervention and control groups were in the same environment, so that they could exchange information about the intervention being carried out, which led to the similarity of information between the intervention and control groups.

Sarin et al. (2013) recommend additional interventions in this School based intervention, which is in the form of awards for students who successfully quit smoking, or awards for schools that succeed in implementing or providing good or maximum interventions. So that it will increase the motivation of students and schools in implementing the interventions given by researchers. Although in his study there was no significant effect of School based intervention on cigarette consumption, the authors recommend offering intervention and strengthening methodology for future researchers, so that there will be a significant increase in the effect of School based intervention on cigarette consumption.

\section{AUTHOR CONTRIBUTION}

Muhammad Rifqi Azhary is the principal researcher who selects topics, searches and collects research data. Eti Poncorini Pamungkasari and Yulia Lanti Retno Dewi played a role in analyzing data and reviewing research documents.

\section{CONFLICT OF INTEREST}

There is no conflict of interest in this study.

\section{FUNDING AND SPONSORSHIP}

This study is self-funded.

\section{ACKNOWLEDGEIMENT}

We are very grateful to the database providers, PubMed, Science Direct and Google Scholar.

\section{REFERENCE}

Blaakman S, Tremblay PJ, Halterman JS, Fagnano M, Borrelli B. (2011). Implementation of a sommunity-based secondhand smoke reduction intervention for caregives of urban children with asthma: process evaluation, successes and challenges. Health Educ Res 28(1):141152.https://doi.org/10.1093/her/cyso7o

Cahill K, Stead LF, Lancaster T. (2012). Nicotine receptor partial agonists for smoking cessation. In Cochrane Database Syst. Rev. (2). https://doi.org/10.1002/14651858.cdoo6103.pub6

CDC. (2020). Youth and Tobacco Use. Retrieved from https://www.cdc.gov/tobacco/data_statistics/fact_sheets/youth_data/tobacco_use/index.htm

CEBM. (2014). Checklist for the Critical Appraisal of a Controlled Study. 10, 12. Retrieved from http://www.cebma.org/wp-content/uploads/Critical- 
Azhary et al./ The Effect of School Based Intervention on Smoking in Adolescents

Appraisal-Questions-for-a-Survey.pdf Cochrane. (2014). RevMan 5.3 User Guide. Drope J, Schluger N, Cahn Z, Drope Ja, Hamill S, Islami F, Liber A, et al. (2018). The Tobacco Atlas. Atlanta: American Cancer Society and Vital Strategies. In the American Cancer Society, Inc. www.tobaccoatlas.org.

FCTC. (2005). Framework Convention on Tobacco Control (FCTC). Pasifik, Asia, 87-90.

Giannotta F, Taglianti FV, Galanti MR, Scatigna M, Faggiano F. (2013). Short-Term Mediating Factors og a School-Based Intervention to Prevent Youth Substanse Use in Europe. J Adolesc Health 54(2014):565-573. http://dx.doi.org/10.1016/j.jadohealt h.2013.10.009

Hodder RK, Freund M, Bowman J, Wolfenden L, Campbell E, Dray J, Lecathelinais $\mathrm{C}$, et al. (2017). Effectiveness of a pragmatic school-based universal resilience intervention in reducing tobacco, alcohol and illicit substance use in a population of adolescents: Cluster-randomised controlled trial. BMJ Open, 7(8). https://doi.org/10.1136/bmjopen-2017-01606o.

Islami SU, Prasetya H, Murti B. (2019). Schools have contextual influence on smoking behavior among high school students in Dumai, Riau. J Health Promot Behav. 4(3): 212-223. https://doi.org/10.26911/thejhpb.2019.04.03.06.

KEMENKES. (2017). Hidup Sehat Tanpa Rokok (Healthy Living Without Smoking). Kementrian Kesehatan Indonesia, ISSN 2442-7659, 06-07.

Lisboa OC, Souza BB, Xavier LEDF, Almeida MR, Correa PCRP, Brinker TJ (2019). A smoking prevention program delivered by medical students to secondary schools in Brazil called "education against tobacco": randomized controlled trial. J Med Internet Res. 21(2): 1-12. https://doi.org/10.2196/12854.

Muller FR, Krist L, Burger C, Strobele NB, Roll S, Rieckmann N, Muller JN, et al. (2014). Berlin evaluation school tobacco prevention-best, prevention: study design and metodology. BMC Public Health. 14(2014): 871-887. https://doi.org/10.1186/1471-245814-871.

Murti B. (2018a). Prinsip dan Metode Riset Epidemiologi (5th ed.) (Principles and Methods of Epidemiological Research (5th ed.)). Program Studi Ilmu Kesehatan Masyarakat, Program Pascasarjana, Universitas Sebelas Maret.

Murti B (2018b). Teori Promosi dan Perilaku Kesehatan (Promotion Theory and Health Behavior). Program Studi Ilmu Kesehatan Masyarakat, Program Pascasarjana, Universitas Sebelas Maret.

Sarin SK, Cavallo DA, Cooney JL, Schepis TS, Kong G, Liss TB, Liss AK, et al. (2013) an exploratory randomized controlled trial of a novel high-schoolbased smoking cessation intervention for adolescent smokers using abstinence-contingent incentives and cognitive behavioral therapy. Drug Alcohol Depend 132(2013): 346-351. http://dx.doi.org/10.1016/j.drugalcdep.2013.03.002.

Sridhar OTS, Murthy P, Kumar KVK. (2020). Integrated brief tobacco and alcohol cessation intervention in a primary health-care setting in Karnataka. Indian J Public Health. 61: 2934 https://doi.org/10.4103/ijph.IJPH_235_17.

Sun P, Miyano J, Rohrbach LA, Dent CW, Sussman S. (2007). Short-term effects of project EX-4: a classroom-based 
Azhary et al./ The Effect of School Based Intervention on Smoking in Adolescents

smoking prevention and cessation intervention and cessation intervention program. Addict Behav 32 (2017): 342-350. https://doi.org/10.1016/j.addbeh.2006.05.005.

Tahlil T, Woodman RJ, Coveney J, Ward PR. (2013). The impact of education programs on smoking prevention: a randomized controlled trial among 11 to 14 year olds in Aceh, Indonesia. BMC Public Health 13 (2013): 367378. https://doi.org/10.1186/14712458-13-367

Tahlil T, Woodman RJ, Coveney J, Ward PR. (2015). Six-months follow-up of a cluster randomized trial of schoolbased smoking prevention education program in Aceh, Indonesia. BMC Public Health. 15 (2015): 1088-1099. https://doi.org/10.1186/s12889-0152428-4.
Thurston A, Dunne L, Kee F, Gildea A, Craig N, Stark P, Lazenbatt A. (2018). A randomized controlled efficacy trial of a smoking prevention programme whit grade 8 student in high schools. Int $\mathrm{J}$ Educ Res. page 0883-0355. https://doi.org/10.1016/j.ijer.2018.10 .003.

Wen X, Chen W, Gans KM, Colby SM, Lu C, Liang C, Ling W. (2010). Randomized controlled trials two-year effect of a school-based prevention programme on adolescent sigarette smoking in Gungzhou, China: a cluster randomized trial. Int J Epidemiol. 39(1):860876. Retrieved from https://doi.org/10.1093/ije/dyqoo1.

WHO. (2014). About youth and tobacco. WHO. Retrieved from https://www.who.int/tobacco/research/youth/yout $\mathrm{h} / \mathrm{en} /$. 